\title{
MOVING STEADILY OR GREAT LEAP FORWARD? THE EMERGING CARBON MARKET IN CHINA
}

\section{YING SHEN*}

China has become a large greenhouse gas ('GHG') emissions source due to its rapid industrialisation and urbanisation. Given the heavy environmental footprint caused by China's economic growth, the Chinese government has recognised the need to control carbon emissions and mitigate climate change. Indeed, China has made remarkable progress in reducing its energy consumption per unit of gross domestic product ('GDP'). However, these improvements are mainly the result of the most readily available abatement options. Given that simple solutions have almost been exhausted, cost-effective market-based instruments such as carbon emissions trading and carbon markets have become the focus of the Chinese leadership's attention and have begun to emerge and develop in China. At this stage the primary issue that must be considered by the Chinese government is how to implement an emissions trading scheme ('ETS') - whether to adopt such a new environmental policy instrument step by step in an evolutionary manner or whether to fully implement it instantly in a revolutionary way. This article considers the future direction of an emerging carbon market in China. It first provides a comprehensive and up-to-date review of current pilot ETS programs in China. Based on the review of these programs, China's pilot ETS programs and the well-established European Union Emissions Trading Scheme ('EU ETS') are compared. The improvements made by, and the shortcomings of, these pilot programs (which could be considered by the Chinese government in choosing an appropriate development model of the ETS in the near future) are summarised. The article concludes by assessing the prospects of an ETS in China.

\section{INTRODUCTION}

The mitigation of carbon emissions has been the subject of gradual policy development in the international community in recent years. ${ }^{1}$ China, as the

\footnotetext{
* PhD Candidate, University of Western Sydney, Australia; LLM, University of Göttingen, Germany; LLM, Nanjing University, China; LLB, Nanjing University, China. The author is grateful to the Deakin Law Review's editors and anonymous referees for their helpful suggestions. Any remaining errors or omissions are those of the author.
} 
world's most populous and largest developing country, has become a major greenhouse gas ('GHG') emissions source due to its rapid industrialisation and urbanisation. ${ }^{2}$ Air pollution within China today, however, is endangering the lives of its citizens and sapping the nation's economic vitality. The heavy environmental impact of its economic growth, has forced the Chinese government to recognise the need to control carbon emissions and mitigate climate change. In the past five years, China has made remarkable progress, achieving an almost 20 per cent reduction in energy consumption per unit of gross domestic product ('GDP'), ${ }^{3}$ thereby contributing to the reduction of carbon emissions. However, this significant improvement is a result largely of the large-scale decommissioning of inefficient power plants, which is one of the most readily available abatement options to reduce China's carbon intensity. ${ }^{4}$ Since simple solutions have almost been exhausted, ${ }^{5}$ it seems that achieving improvements on a similar scale will become increasingly difficult and challenging in the future. In this context, cost-effective market-based instruments have become the focus of attention for Chinese leaders; in particular, carbon emissions trading and carbon markets are beginning to emerge and develop in China.

1 The 1992 United Nations Framework Convention on Climate Change ('UNFCCC') recognised the principle of the global cost-effectiveness of emissions reduction, opening the way for tradable permits. In December 1997, industrialised countries and countries with economies in transition, also known as 'Annex I countries', agreed to a legally binding commitment at the third meeting of the Conference of Parties held in Kyoto, negotiating a legal framework as a protocol to the UNFCCC - the Kyoto Protocol. See United Nations Framework Convention on Climate Change, opened for signature 9 May 1992, 1771 UNTS 107 (entered into force 21 March 1994); Kyoto Protocol to the United Nations Framework Convention on Climate Change, opened for signature 11 December 1997, 2303 UNTS 162 (entered into force 16 February 2005).

${ }^{2}$ According to a recent inventory of the International Energy Agency ('IEA'), China is now the world's largest source of fossil fuel energy-related GHG emissions, surpassing the United States ('US'). See IEA, $\mathrm{CO}_{2}$ Emissions from Fuel Combustion: Highlights (OECD/IEA, 2012) 24.

${ }^{3}$ Andreas Tuerk et al, 'Emerging Carbon Markets: Experience, Trends, and Challenges' (Working Paper, Climate Strategies, 1 January 2013) $12<$ http://www.climatestrategies. org/research/our-reports/category/63/370.html>.

${ }^{4}$ Under severe scrutiny towards the end of 2010, data showed that many energy managers stopped or slowed production rather than improving efficiency to achieve their targets of lowering energy intensity. This resulted in a slight 'rebound' of energy intensity in early 2011. See Jane A Leggett, 'China’s Greenhouse Gas Emissions and Mitigation Policies' (CRS Report for Congress No R41919, Congressional Research Service, 2011) 16.

${ }^{5}$ In addition to the closure of thousands of small, inefficient and polluting coal-fired power plants, iron and steel mills, cement kilns, aluminium plants, etc, China has also tried to increase its share of non-fossil energy through using clean and renewable energy, such as wind power. The Chinese government has also tried other solutions, such as storing carbon in forests, improving the enforcement of standards, giving monetary awards for energy-saving achievements by companies and public institutions and tightening efficiency standards for buildings and appliances. See Leggett, above n 4, 17. 
Mr Deng Xiaoping, the chief designer of China's modernisation drive, once quoted the proverb of 'crossing the river by groping for stones' when facing the challenges of economic reform. ${ }^{6}$ As a metaphor for progress it implies moving steadily while trying new things. As a brand new environmental policy instrument, the emissions trading scheme ('ETS') is presenting new challenges for the Chinese government. How to implement the ETS in China - either by adopting this market-based environmental policy instrument steadily in a gradual and evolutionary manner, or fully implementing it instantly in the revolutionary manner of the Great Leap Forward ${ }^{7}$ - is the primary issue that must be considered by the Chinese government at this stage. This article considers the future direction of an emerging carbon market in China. It first provides a comprehensive and up-to-date review of current pilot ETS programs in China. Seven pilot regions in China are divided into three groups: first movers (Beijing, Shanghai and Guangdong); pilot regions with official implementation plans (Tianjin, Hubei and Shenzhen); and the pilot region without an official implementation plan (Chongqing). Based on the review of these pilot ETS programs, China's pilot programs are compared with the well-established European Union Emissions Trading Scheme ('EU ETS'). The improvements made by, and the shortcomings of, these pilot programs, which could be considered by the Chinese government in choosing an appropriate development model of the ETS in the near future, are then summarised. The article concludes by assessing the prospects of an ETS in China.

\footnotetext{
${ }^{6}$ Strictly speaking, the political slogan of 'crossing the river by groping for stones' was first proposed by Chen Yun on 7 April 1950 and was mentioned several times at a series of central conferences. On 16 December 1980, Chen Yun pointed out at the Central Working Conference that reform in China should be kept steady like a person crossing a river by groping for stones, which Deng Xiaoping completely agreed with. This political slogan was later promoted by Deng Xiaoping in the article 'Reform is China's Second Revolution' on 28 March 1985 and is deemed to be one of the classic quotations from Deng Xiaoping. See 陈云 [Chen Yun], 《陈云文选第 3 卷》 [Selected Works of Chen Yun Volume III] (人民出版社 [People's Publishing House], 1993) 279; 邓小平 [Deng Xiaoping], 《邓小平文选第 3 卷》 [Selected Works of Deng Xiaoping Volume III] (人民出版社 [People’s Publishing House], 1993) 174.

${ }^{7}$ The Great Leap Forward in Chinese history dates back to the 'planned economy' period, which was an economic and social campaign launched by the Communist Party of China between 1958 and 1960. It aimed at transforming China from an agrarian economy into a modern communist society through the process of rapid industrialisation and agricultural collectivisation. For more information on the Great Leap Forward, see Theodore Shabad, 'China’s “Great Leap Forward”' (1959) 28(7) Far Eastern Survey 105, 105-9.
} 


\section{Initiating Pilot Programs for Carbon Emissions TRADING IN CHINA}

The Outline of the Twelfth Five-Year Plan for National Economic and Social Development of the People's Republic of China (2011-2015) ${ }^{8}$ foreshadows the development of carbon emissions trading, anticipating the 'step by step establishment of carbon emissions trading markets' ${ }^{9}$ so as to 'give full play to the fundamental role of the market mechanism in optimizing the allocation of resources, and realize the objective of controlling greenhouse gas emissions at minimum cost' ${ }^{10}$ Based on this Outline, carbon emissions trading is being tested through specific pilot programs in parts of China. When discussing the initiative pilot programs of carbon emissions trading in China, it is necessary to clarify two types of ETS. The first is voluntary emissions trading, which is based upon previous pilot programs conducted at the local level. The first batch of pilot programs dates back to 2008, when emissions trading exchanges were set up in Beijing, Shanghai and Tianjin. ${ }^{11}$ Subsequently, voluntary emissions trading began to emerge in China, with the establishment of a series of technical standards and financial channels. Voluntary emissions trading recruits participants from industries and organisations who agree to make reductions in their carbon emissions rather than being compelled to do so. The second type of ETS is mandatory emissions trading, which is currently being piloted in four municipalities, two provinces and one local-level city in China (Figure 1). A mandatory ETS generally refers to an ETS that requires particular sectors (for example, energy-intensive industry sectors such as oil refineries, steel works and works producing iron, aluminium, metals, cement, lime, and so forth) to participate in the scheme compulsorily in relation to particular GHGs, such as $\mathrm{CO}_{2}{ }^{12}$

\footnotetext{
8 国家发展和改革委员会 [National Development and Reform Commission (NDRC)], 《中华 人民共和国国民经济和社会发展第十二个五年规划纲要》 [The Outline of the Twelfth Five-Year Plan for National Economic and Social Development of the People's Republic of China] (14 March 2011) <http://www.ndrc.gov.cn/fzgh/ghwb/gjjh/P02011091959220857 5015.pdf $>$.

${ }^{9}$ Ibid.

${ }^{10}$ The Information Office of the State Council of People's Republic of China, China's Policies and Actions for Addressing Climate Change (November 2011) Chinese Government's Official Web Portal <http://www.gov.cn/english/official/2011-11/22/content_2000272_ 8.htm>.

${ }^{11}$ International Emissions Trading Association ('IETA'), 'The World's Carbon Markets: A Case Study Guide to Emissions Trading’ (IETA, 2013) $3<$ http://www.ieta.org/assets/Reports/ EmissionsTradingAroundTheWorld/edf_ieta_china_case_study_september_2013.pdf>.

${ }^{12}$ Current mandatory ETSs are provided for by the Kyoto Protocol, the EU ETS, Australia's Carbon Price Mechanism, the New Zealand ETS, the Swiss ETS, the South Korean ETS, the Kazakhstan ETS and some regional schemes (eg, the Regional Greenhouse Gas Initiative in the US, the Western Climate Initiative between the US and Canada, etc). See Anita Talberg
} 
Current pilot ETS programs in China could be considered mandatory in nature, though they have not been officially defined. ${ }^{13}$ One major advantage of a mandatory ETS over a voluntary one is that it can ensure the achievement of the mitigation target, whereas the target set by a voluntary emissions trading scheme is more flexible due to the voluntary or elective nature of the scheme. Therefore, a mandatory ETS would be more appropriate as a national model aimed at targeted mitigations across the economy. On the other hand, during the early stages of introducing an ETS in China, a voluntary ETS is politically more feasible and likely to gain more support from industries. For enterprises not involved in a mandatory ETS, a major benefit of a voluntary ETS stems from learning-by-doing and from institutional capacity-building within the sectors. Starting out with a voluntary ETS would provide the advantage of enabling participants to develop reduction skills and learn trading strategies that may be useful as the national ETS model develops in the future. Moreover, a successful voluntary ETS should be cost-effective and have low administrative costs, since the incentive to pursue voluntary emissions trading is inversely proportional to the cost of the action that needs to be taken to achieve the reduction target.

Hence, the Chinese government has chosen to implement voluntary emissions trading programs initially to gain experience before launching mandatory ETS pilot programs in the above-mentioned seven regions. Based on these pilot ETS programs, the government has declared that a national ETS is to be established during the Thirteenth Five-Year Plan period (2016-2020). ${ }^{14}$ However, due to the uncertainties of carbon prices globally, and in particular in the European Union ('EU'), the operation of such a scheme in China is likely to be postponed.

and Kai Swoboda, Emissions Trading Schemes around the World (6 June 2013) Parliament of Australia <http://www.aph.gov.au/About_Parliament/Parliamentary_Departments/Parliament ary_Library/pubs/BN/2012-2013/EmissionsTradingSchemes\#_ftnref25>.

13 Tuerk et al, above n 3, 13 .

${ }^{14}$ IETA, above n 11, 3. 


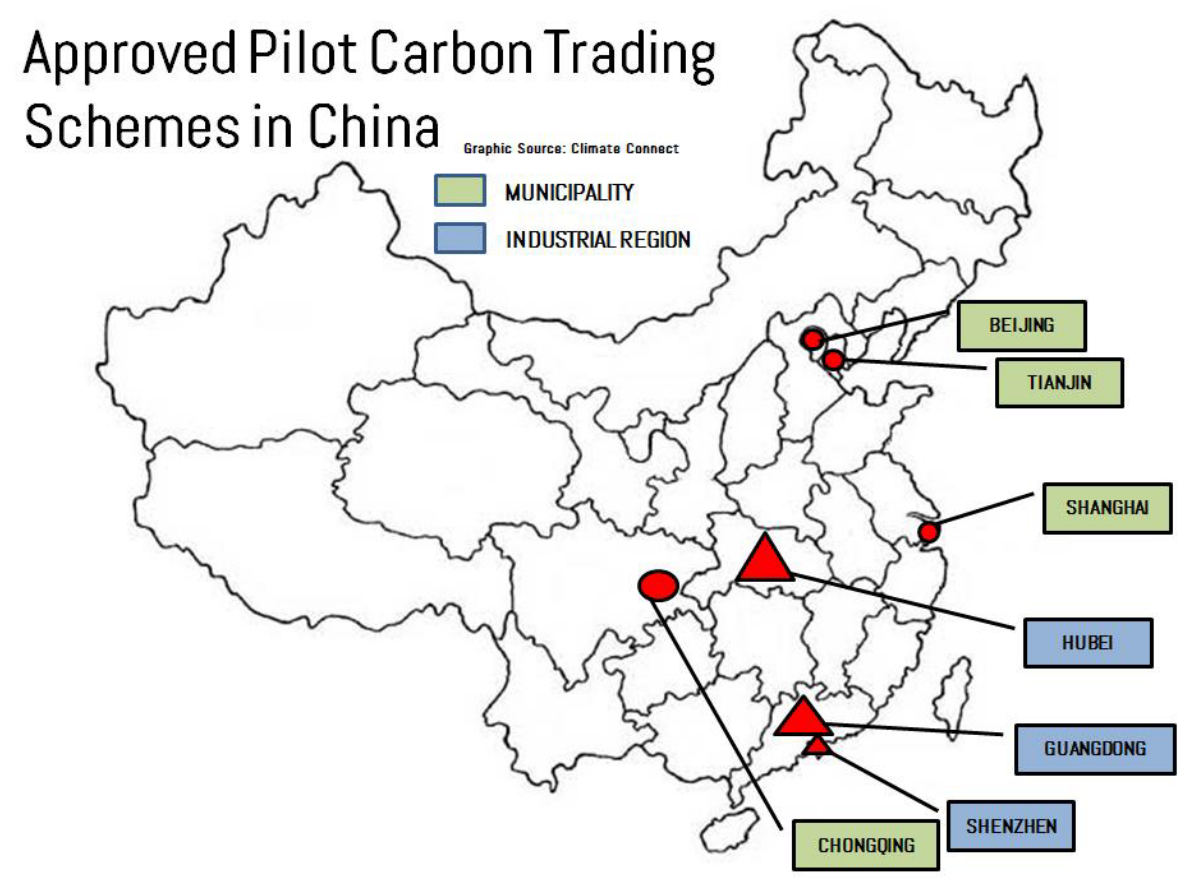

Figure 1 Pilot Carbon Trading Schemes in China (Source: Climate Connect) ${ }^{15}$

\section{A Establishing a Voluntary ETS in China}

Voluntary emissions trading in $\mathrm{CO}_{2}$ commenced during the Eleventh FiveYear Plan (2006-2010) period in China. ${ }^{16}$ In order to formalise the voluntary emissions reduction exchange, a number of standards were designed and published. For example, the Panda Standard, the first Chinese domestic voluntary carbon standard, was established by the China Beijing Environment Exchange ('CBEEX'), BlueNext and Winrock International. ${ }^{17}$ This standard was designed to provide transparency and credibility in the initial Chinese carbon market, an aim which is reflected in its project approval process. ${ }^{18}$ For

\footnotetext{
${ }^{15}$ Climate Connect, China May Introduce Futures Trading of Emission Permits under Pilot ETS (4 September 2012) <http://www.climate-connect.co.uk/Home/?q=node/2651>.

${ }^{16}$ Tuerk et al, above n 3, 14; IETA, above n 11, 3.

${ }^{17}$ Version 1.0 of the standard was launched at the $15^{\text {th }}$ meeting of the Conference of Parties in Copenhagen in December 2009. See Stockholm Environment Institute ('SEI'), Panda Standard (January 2011) Carbon Offset Research \& Education <http://co2offset research.org/policy/PandaStandard.html>.

${ }^{18}$ Panda Standard version 1.0 is the reference document of the Panda Standard describing the overall organisation of the Panda Standard Association as well as the core procedures of its
} 
example, validation of registered Panda Standard projects must be performed by an independent third party auditor, who is required to visit on site at least once. ${ }^{19}$ The independent third party auditor is required to perform monitoring, verification and certification tasks as well. ${ }^{20}$ To ensure the credibility of registered Panda Standard projects, verification must be performed at least every five years as well as upon any application for renewal of a project's crediting period. ${ }^{21}$ In addition to the chosen pilot ETS cities and provinces, other cities and provinces have also implemented certain voluntary emissions trading at the local level. However, the current market performance of these voluntary emissions trading schemes scores relatively low due to the lack of infrastructure and the shortage of incentives for participating enterprises. ${ }^{22}$

Lack of demand has long challenged voluntary emissions trading. During 2009, the trading volume on the global carbon market was 8.7 billion tons of carbon dioxide equivalent (' $\mathrm{CO}_{2} \mathrm{e}$ '), among which the voluntary emissions trading volume accounted for only one per cent. ${ }^{23}$ The voluntary emissions trading volume in China is even lower. For example, the CBEEX surpassed its peers with a total trade volume of three million tons of $\mathrm{CO}_{2} \mathrm{e}$ in the first three years of operation, but this is still less than the European Climate Exchange's trade volume in a single day. ${ }^{24}$ Therefore, provinces and cities are now developing further voluntary emissions trading schemes so as to gather practical experience and explore appropriate strategies and tactics for better market performance. For example, in Shenzhen city, a project that can generate verified emission reductions ('VERs') based on new-energy vehicles rolled out in the public transport sector in the city was implemented during the 2011 Shenzhen University Games. ${ }^{25}$ In Hubei province, a voluntary carbon

project certification scheme. See Panda Standard, What is the Panda Standard? (2010) <http://www.pandastandard.org/standard/standard.html $>$. The full text of Panda Standard version 1.0 is available at <http://www.pandastandard.org/downloads/PandaStandard_v1 ENGLISH.pdf>.

${ }^{19}$ SEI, above n 17.

20 Ibid.

21 Ibid.

22 Tuerk et al, above n 3, 14.

23 李梅影 [Li Meiying], 《自愿减排交易管理办法拟出 减排量将审核签发》[Regulations of Voluntary Emissions Trading will be drawn up, Emissions Reduction will be issued through verification], 低碳周刊 Carbon Weekly (21 世纪经济报道) [21 $1^{\text {st }}$ Century Business Herald], 22 February 2011, 21.

${ }^{24}$ Haibing Ma, Cloud of Uncertainty Hovers over China's New Emissions Trading Plans (10 February 2012) Worldwatch Institute <http://blogs.worldwatch.org/revolt/cloud-ofuncertainty-hovers-over-chinas-new-emissions-trading-plans/>.

25 田然 [Tian Ran], 《深圳新能源汽车尝试碳交易》[Shenzhen Tests Carbon Emissions Trading on New Energy Vehicles], 深圳特区报 Shenzhen News (online), 31 July 2011 <http://gov.finance.sina.com.cn/chanquan/2011-08-01/101794.html> A2. 
emissions trade was finalised in early 2012 whereby 20000 tons of GHGs were purchased by two firms. ${ }^{26}$

In the hope of promoting low-carbon pilot projects and providing general guidelines to establish a voluntary emissions trading market at the national level, the Interim Regulation of Voluntary Greenhouse Gases Emission Trading in China ${ }^{27}$ ('the Interim Regulation') was issued by the National Development and Reform Commission ('NDRC') on 13 June 2012. The Interim Regulation outlines the basic management framework, trading procedures and supervisory measures of the voluntary trading scheme. In a bid to ensure that trading proceeds in an orderly fashion, the Interim Regulation establishes a registration and recording system and an information disclosure system, and encourages project-based voluntary GHG emissions trading. According to this Interim Regulation, projects generating additional emission mitigations of six GHGs $\left(\mathrm{CO}_{2}, \mathrm{CH}_{4}, \mathrm{~N}_{2} \mathrm{O}, \mathrm{HFCs}, \mathrm{PFCs}, \mathrm{SF}_{6}\right)$ are permitted to participate in a national voluntary ETS governed by the NDRC. ${ }^{28}$ However, most project-based voluntary emission exchange markets still operate at the provincial or city level, and there is no clear linkage between local voluntary ETSs and national voluntary ETSs. ${ }^{29}$ Therefore, it is essential for the government to clarify how to promote voluntary emissions exchange at the national level and how to link the local voluntary emissions exchange market with the national voluntary market. This might to some extent undermine the efficacy of the pilot programs in terms of their suitability for national roll out, given that industries would prefer voluntary emissions trading to mandatory pilot programs. In this regard, the government needs to coordinate the two systems and avoid potential 'carbon leakage'. 30

26 冯欣楠 [Feng Xinnan], 《华中首个自愿性碳交易敲定》[A First Voluntary Carbon Emissions Trading Has Been Finalized in Central China], 长江日报 Changjiang News (online), 15 January 2012 <http://cjmp.cnhan.com/cjrb/page/1/2012-01-15/5/6694132 6567299307.pdf $>5$.

${ }^{27}$ The Climate Group, The Interim Regulation of Voluntary Greenhouse Gases Emission Trading in China (July 2012) The Clean Revolution <http://thecleanrevolution.org/_assets/ files/Interim-Regulation-of-Voluntary-Greenhouse-Gases-Emission-Trading-in-China(1). pdf $>$.

${ }^{28}$ Interim Regulation of Voluntary Greenhouse Gases Emission Trading in China, §§ 2, 4-5 (2012).

${ }^{29}$ Tuerk et al, above n 3, 14 .

${ }^{30}$ Carbon leakage refers to the increase of carbon emissions outside a country (or a region) with an ambitious carbon pricing regime (eg, an ETS). Dröge et al have identified three channels through which carbon leakage is affected by unilateral carbon pricing: (1) global energy markets; (2) a firm's production costs and its operation and investment decisions; and (3) the dynamics of technological innovation and policy diffusion. A detailed discussion of this issue is provided below in Part III H. See Dröge et al, 'Tackling Leakage in a World of Unequal Carbon Prices' (Climate Strategies, 2009) 16. 


\section{B Conducting Carbon Emissions Trading Pilot Programs}

In 2011, a series of pilot programs for carbon emissions trading operating in a similar way to the EU ETS were initiated by the NDRC in four municipalities (Beijing, Tianjin, Shanghai and Chongqing), two provinces (Hubei and Guangdong) and one local-level city Shenzhen (in Guangdong province). ${ }^{31}$ Organisations and leadership were strengthened and professional teams were allocated funds earmarked for the pilot programs in these designated areas. These seven regions, in aggregate, account for 18 per cent of China's population and 28 per cent of its national GDP, but their energy and carbon intensity are below China's national average level. ${ }^{32}$ Given that an ETS is usually a learning-by-doing process, and that learning costs during the early stage might be relatively high due to the high uncertainty of economic growth and development, the primary reason why these regions were selected as pilot regions to conduct pilot ETSs was not their energy and carbon intensity, but their capacity to pay for the high learning costs. ${ }^{33}$ It is generally recognised that choosing richer regions as pilot regions first can minimise nationwide learning costs in the long run; other regions, especially poorer ones, can run ETSs later upon the experience and lessons learned from these pilot regions. ${ }^{34}$ However, it would make no sense to evaluate the pilot programs' success in terms of potential GHG emissions reductions if these reductions are being tested in low emitting jurisdictions only. Therefore, it is essential for the government to consider gradually including more carbon-intensive regions into the programs.

When running carbon emissions trading pilot programs, each of the designated areas is obliged to compile an implementation plan for the program in its area, defining the overall concept, objectives, key tasks, safeguards and project schedules. ${ }^{35}$ Based on this implementation plan, the areas can research and formulate regulations for the program and work out its basic rules. ${ }^{36}$ Policy makers also have to calculate and define overall caps for GHG emissions in their regions and work out plans for distributing specific

\footnotetext{
31 NDRC, China's Policies and Actions for Addressing Climate Change (2012) $<$ http://qhs.ndrc.gov.cn/zcfg/W020121122588539459161.pdf>; 国家发展改革委办公厅 [General Office of the National Development and Reform Commission], 《国家发展改革委 办公厅关于开展碳排放权交易试点工作的通知》 [Circular of the General Office of the NDRC on Launching Pilot Carbon Emissions Trading Programs] (29 October 2011) <http://www.ndrc.gov.cn/zcfb/zcfbtz/2011tz/t20120113_456506.htm>.

${ }^{32}$ Tuerk et al, above n 3,14 .

${ }^{33}$ Ibid $14-15$.

${ }^{34}$ Ibid 15.

${ }^{35}$ NDRC, above n 31.

${ }^{36}$ Ibid.
} 
emissions targets. ${ }^{37}$ In a bid to implement the pilot programs more smoothly, support systems, such as regulatory, registration and recording systems, and trading platforms, have been established and developed in each pilot area. ${ }^{38}$ Generally speaking, the pilot ETS at local level adopts a bottom-up approach, which complements the top-down approach of the Twelfth Five-Year Plan. It is worth noting that each pilot program is sui generis, since each implementation plan is formulated by local government in line with its local conditions. Therefore, there is no common implementation standard for these pilot regions. However, in the absence of a common implementation standard, the NDRC would not be able to evaluate the efficacy of the pilot programs vis-à-vis each other for a national ETS. It is hard to say whether this is a design flaw in the NDRC pilot policy, or whether it is deliberate to enable a suite of options for the NDRC to choose from. If it is a design flaw, the NDRC is expected to take this issue into account and set an appropriate common implementation standard for a national roll out.

\section{First Movers of Pilot ETSS In China: BeiJing, SHANGHAI AND GUANGDONG}

Beijing, Shanghai and Guangdong launched their pilot programs on 28 March 2012, 16 August 2012 and 11 September 2012, respectively, ${ }^{39}$ becoming the first movers in designing local ETS implementation plans in China. While Beijing announced that its pilot ETS implementation plan had been formulated in March 2012, the plan has still not been published. ${ }^{40}$ Following Beijing, Shanghai and Guangdong set out and published their implementation plans in July 2012 and September 2012, respectively. ${ }^{41}$ On 18 November

\footnotetext{
37 Ibid.

38 Ibid.

39 Ibid.
}

40 《七省市排放权交易试点进程》 [Progress on Pilot ETS Programs in Seven Provinces and Cities], 低碳工业网 Low Carbon Industry (online), 22 April 2013 <http://www. tangongye.com/news/NewShow.aspx?id=12074>. Since there is no public access to Beijing's pilot ETS implementation plan, materials and data used in this article are based on secondary data.

41 上海市人民政府 [Shanghai Municipal People’s Government], 《上海市人民政府关于本市 开展碳排放交易试点工作的实施意见》 [Opinions of Shanghai Municipal People's Government on the Implementation of Pilot Carbon Emissions Trading Programs in Shanghai] (3 July 2012) <http://www.shanghai.gov.cn/shanghai/node2314/node2319/node12344/u26ai 32789.html>; 广东省人民政府 [People's Government of Guangdong Province], 《广东省碳 排放权交易试点工作实施方案》 [Implementation Plan for Pilot Carbon Emissions Trading Programs in Guangdong Province] (7 September 2012) <http://zwgk.gd.gov.cn/006939 748/201209/t20120914_343489.html>. 
2013 during the Warsaw Climate Change Conference, ${ }^{42}$ Xie Zhenhua, the deputy director of the NDRC, indicated that Shanghai and Beijing would launch their pilot ETS programs on 26 November 2013 and 28 November 2013, respectively. ${ }^{43}$ Guangdong is also expected to initiate its pilot emissions trading program by the end of $2013 .^{44}$

\section{A Pilot Period}

Most pilot regions will implement their pilot ETS programs between 2013 and 2015, with no regulation in place for the post-2015 period, which is considered a transition period from the pilot ETS to a nationwide ETS. ${ }^{45}$ It is notable that Guangdong has set a 2020 target, aiming to establish a mature intra-provincial ETS as a solid foundation for an inter-provincial ETS. ${ }^{46}$ This implementation plan is divided into three phases - Phase I (2012-2015) is the pilot trial period, Phase II (2016-2020) is the trial perfecting period, and Phase III (after 2020) is the mature operating period. ${ }^{47}$ Although the Guangdong 2020 target intends to lay a foundation for a nationwide ETS by establishing an intra-provincial ETS, it is still not clear whether the post-2015 provincial ETS will be compatible with the nationwide ETS, given that no official information on a nationwide ETS is available to date. Considering the uncertainties and risks involved in the ETS, the NDRC is still waiting to see the results of these provincial pilots.

\section{B Scope of the Cap's Coverage}

The scope of the cap's coverage - that is, what emission sources and types of GHG emissions will be subjected to the overall cap - differs from region to region and depends on criteria such as the sector, and emission load.

\section{$1 \quad$ Beijing}

According to the Implementation Plan for Pilot Carbon Emissions Trading Programs in Beijing (2012-2015) (the 'Beijing Pilot Implementation Plan'),

\footnotetext{
${ }^{42}$ The $19^{\text {th }}$ session of the Conference of the Parties to the UNFCCC was held in Warsaw, Poland between 11 November 2013 and 22 November 2013.

43 《解振华: 上海北京碳市场本月底将相继启动交易》 [Xie Zhenhua: Carbon Emissions Trading Will Be Launched in Shanghai and Beijing at the End of this Month Successively] (19 November 2013) <http://politics.people.com.cn/n/2013/1119/c70731-23582773.html>.

${ }^{44}$ Ibid.

${ }^{45}$ Tuerk et al, above n 3, 15 .

${ }^{46}$ Ibid.

47 广东省人民政府 [People’s Government of Guangdong Province], above n 41.
} 
enterprises with annual $\mathrm{CO}_{2}$ emissions during 2009-2011 higher than 10000 tons, including direct $\mathrm{CO}_{2}$ emissions and indirect $\mathrm{CO}_{2}$ emissions from electricity consumption, will be included in the mandatory pilot ETS. ${ }^{48}$ There being no sectoral boundary in this implementation plan, all sectors will be included in Beijing's pilot ETS as long as their annual $\mathrm{CO}_{2}$ emissions exceed 10000 tons. Compared to the ETSs with sectoral boundaries (such as the EU ETS, which covers only electric utilities, heavy industry and commercial aviation), the Beijing Pilot Implementation Plan is more straightforward, given that the objective of the benchmark is emissions reductions across the board rather than reductions in certain sectors. However, without sectoral boundaries, the relevant monitoring, reporting and verification ('MRV') work would be burdensome. As a result, implementation costs would increase. Therefore, including all sectors into the ETS is not economically efficient.

According to the Beijing Pilot Implementation Plan, tradable emissions allowances ${ }^{49}$ in this pilot ETS are direct $\mathrm{CO}_{2}$ emissions, indirect $\mathrm{CO}_{2}$ emissions and Chinese Certified Emission Reductions ('CCERs') generated from China's voluntary emissions trading activities. ${ }^{50}$ It is worth noting that the trading of indirect $\mathrm{CO}_{2}$ emissions is a new initiative that has not been carried out anywhere in the world yet. The primary reason for including indirect $\mathrm{CO}_{2}$ emissions trading in the Beijing Pilot Implementation Plan is that more than 60 per cent of the electricity consumed in Beijing is purchased outside Beijing. ${ }^{51}$ For this reason, indirect $\mathrm{CO}_{2}$ emissions become the dominant emissions in Beijing, a fact which cannot be ignored. This is an ambitious aspect of the Chinese pilot programs that has the potential to raise standards in other countries. However, no further specific details on whether

${ }^{48}$ Tuerk et al, above n 3, 15; 李梅影 [Li Meiying], 《北京启动碳排放权交易试点 拟强制纳 入 600 单位》 [Beijing Launched Pilot Carbon Emissions Trading Programs, Intending to Include 600 Enterprises in the Mandatory Pilot ETS], 新浪财经 finance.sina.com.cn (online), 3 April $2012<$ http://finance.sina.com.cn/roll/20120403/025611740880.shtml>.

${ }^{49}$ The emissions allowance refers to a unit issued by a central authority (normally the government) allowing its holder to emit one emission unit under an emissions trading scheme (such as the EU ETS). For example, according to art 3(a) of the Directive 2003/87/EC of 13 October 2003, the allowance under the EU ETS means "an allowance to emit one tonne of carbon dioxide equivalent during a specific period, which shall be valid only for the purposes of meeting the requirements of this Directive and shall be transferable in accordance with the provisions of this Directive". See the European Parliament and the Council of the European Union, 'Directive 2003/87/EC of the European Parliament and of the Council of 13 October 2003: establishing a scheme for greenhouse gas emission allowance trading within the Community and amending Council Directive 96/61/EC' (25 October 2003) Official Journal of the European Union L 275/32, L 275/34, Article $3<$ http://eur-lex.europa.eu/Lex UriServ/LexUriServ.do?uri=OJ:L:2003:275:0032:0032:EN:PDF>. A detailed discussion on emissions allowance distribution is provided below in Part III D.

${ }^{50}$ Tuerk et al, above n 3, 15; 李梅影 [Li Meiying], above n 48.

51 李梅影 [Li Meiying], above n 48. 
allowances of direct and indirect $\mathrm{CO}_{2}$ emissions have the same value and whether they can be mixed and exchanged freely are given in this implementation plan. There is also no explicit definition of the upper boundary of the use of CCERs, which is expected to be further studied and set by Beijing Municipal Government as soon as possible.

\section{Shanghai}

Unlike Beijing's Pilot Implementation Plan, Shanghai's plan sets a clear sectoral boundary, stating that enterprises from the industrial sectors of iron and steel, petrochemicals, chemicals, non-ferrous metal, electricity, building materials, textiles, pulp and paper, rubber and chemical fibre, with annual direct and indirect $\mathrm{CO}_{2}$ emissions during 2010-2011 above 20000 tons will be included in the mandatory pilot ETS. ${ }^{52}$ Enterprises from the non-industrial sectors of aviation, ports (shipping), airports, railways, commerce, hotels and finance with annual $\mathrm{CO}_{2}$ emissions during 2010-2011 above 10000 tons will be included in this ETS as well. ${ }^{53}$ Enterprises included in the pilot ETS are referred to as 'pilot enterprises' hereinafter. It can be seen that there is a clear sectoral boundary in Shanghai's pilot ETS implementation plan, which is similar to the EU ETS. With such a sectoral boundary, the implementation costs will be reduced. As in the Beijing Pilot Implementation Plan, indirect $\mathrm{CO}_{2}$ emissions are included in this program as well, which is an improvement compared to other well-established ETSs elsewhere in the world (such as the EU ETS).

According to Shanghai's pilot ETS implementation plan, other enterprises with annual $\mathrm{CO}_{2}$ emissions during 2012-2015 higher than 10000 tons, that are not included in the pilot ETS, are required to report their $\mathrm{CO}_{2}$ emissions during the pilot period as a preparatory step for the expansion of pilot programs in the next stage. ${ }^{54}$ These enterprises are hereinafter referred to as 'reporting enterprises'. The regulation with regard to reporting enterprises is an advantage, given that potential emissions sources are taken into account in this program. This aspect is an application of the precautionary principle ${ }^{55}$, which keeps the scope of the cap's coverage open in the face of emissions

52 上海市人民政府 [Shanghai Municipal People’s Government], above n 41.

${ }^{53}$ Ibid.

${ }^{54}$ Ibid.

${ }^{55}$ Briefly stated, the precautionary principle ensures that a substance or activity posing a threat to the environment is prevented from adversely affecting the environment, even if there is no conclusive scientific proof linking that particular substance or activity to environmental damage. See James Cameron and Juli Abouchar, 'The Precautionary Principle: A Fundamental Principle of Law and Policy for the Protection of the Global Environment' (1991) 14(1) Boston College International and Comparative Law Review 1, 2. 
uncertainty. For reporting enterprises, this regulation is like the sword of Damocles hanging above their heads. The possibility of being covered by the ETS will make them pay more attention to their emissions and prompt them to take emissions reduction measures.

In terms of types of GHG emissions subjected to the cap, this pilot program focuses exclusively on $\mathrm{CO}_{2}$, which is different from the current EU ETS. In addition to $\mathrm{CO}_{2}$ emissions from power plants and a wide range of energyintensive industry sectors and commercial airlines, nitrous oxide (' $\mathrm{N}_{2} \mathrm{O}$ ') emissions from the production of certain acids (such as nitric, adipic, glyoxal and glyoxylic acids) and emissions of perfluorocarbons ('PFCs') from aluminium production are also included in the EU ETS. ${ }^{56}$ Although $\mathrm{CO}_{2}$ makes a significant contribution to global warming, some non- $\mathrm{CO}_{2} \mathrm{GHGs}$, such as methane (' $\mathrm{CH}_{4}$ '), $\mathrm{N}_{2} \mathrm{O}$ and ozone (' $\mathrm{O}_{3}$ '), also have impacts on GHG concentrations. ${ }^{57}$ For this reason, some non- $\mathrm{CO}_{2}$ GHG emissions should also be controlled under the same framework as $\mathrm{CO}_{2}$ emissions in a multi-gas ETS. However, during the initial phase of the EU ETS (2005-2007), due to the EU's limited experience with emissions trading, the scope of the ETS covered only $\mathrm{CO}_{2}$ emissions from large emitters in the power and heat generation industry as well as in selected energy-intensive industrial sectors. ${ }^{58}$ This scope was expanded during the second period of the EU ETS (20082012), with the inclusion of $\mathrm{N}_{2} \mathrm{O}$ emissions from the production of certain acids and emissions of PFCs from aluminium production. Based on this experience, during the initial pilot period, China's ETS will exclusively cover $\mathrm{CO}_{2}$ emissions before including other non- $\mathrm{CO}_{2}$ GHG emissions in the system.

Tradable emissions allowances in Shanghai's pilot ETS are $\mathrm{CO}_{2}$ emissions, complemented by CCERs and other project-based credits authorised by Shanghai local government. ${ }^{59}$ It can be seen that pilot enterprises are allowed to use credits from emissions mitigation mechanisms that are outside the ETS's scope of coverage to offset some of their emissions so as to achieve compliance obligations. This measure is usually undertaken by many ETSs (for example, the EU ETS) to reduce cost uncertainty. ${ }^{60}$

\footnotetext{
${ }^{56}$ European Commission, The EU Emissions Trading System (EU ETS) (31 October 2013) European Commission Climate Action <http://ec.europa.eu/clima/policies/ets/>.

${ }^{57}$ T J Blasing, Recent Greenhouse Gas Concentrations (February 2013) Carbon Dioxide Information Analysis Center <http://cdiac.ornl.gov/pns/current_ghg.html>.

58 Slobodan Perdan and Adisa Azapagic, 'Carbon Trading: Current Schemes and Future Developments’ (2011) 39 Energy Policy 6040, 6043.

59 上海市人民政府[Shanghai Municipal People’s Government], above n 41.

60 The uncertainty about future allowance prices may prevent enterprises taking up socially desirable and capital-intensive emissions mitigation investments, compelling heavier reliance on less capital-intensive but more costly measures, thereby increasing the long-run cost of
} 
Similarly to Shanghai's pilot ETS implementation plan, Guangdong sets out the scope of its cap's coverage during Phase I (2012-2015) upon criteria of both sectoral boundaries and emission load, stating that enterprises from the industrial sectors of electricity, cement, iron and steel, ceramics, petrochemicals, textiles, non-ferrous metal, plastic as well as pulp and paper with annual $\mathrm{CO}_{2}$ emissions during 2011-2014 above 20000 tons (or total comprehensive energy consumption above 10000 tons of standard coal) will be included in the mandatory pilot ETS. ${ }^{61}$ These enterprises included in the pilot ETS are hereinafter referred to as 'emissions-control enterprises'. By the end of the Twelfth Five-Year Plan period, transport and building sectors are supposed to be included in this ETS. ${ }^{62}$ The choice of the years between 2011 and 2014 differs from Beijing's and Shanghai's, indicating that new enterprises that have not been included initially before the implementation of the pilot ETS by early 2013 may be included in this ETS as late as 2014 as long as their $\mathrm{CO}_{2}$ emissions exceed the regulated threshold. ${ }^{63}$ Tradable allowances in this pilot ETS cover $\mathrm{CO}_{2}$ emissions, supplemented by CCERs and other project-based credits authorised by Guangdong province. ${ }^{64}$

\section{System's Cap Setting}

To date no quantitative cap has been set in the pilot ETS implementation plans of these three regions. These implementation plans only indicate the objective of setting a total amount target for carbon emissions during the pilot period rather than providing specific quantities for caps. Therefore, the system's cap is more an aspiration than a target. Given that pilot ETSs are expected to be officially operating from 2013 in all seven regions, it is necessary to set the precise cap as soon as possible.

Setting a reasonable and feasible emissions target - that is, the system's cap - is one of the essential elements of an ETS, since the targeted emissions mitigation over the targeted period of time is among the most important

emission caps. In response, much attention has been given to including 'cost-containment' mechanisms (eg, credits mechanism) in the ETS to reduce cost uncertainty. Other 'costcontainment' mechanisms in the ETS, such as banking and borrowing, are discussed below. See Robert N Stavins, 'Addressing Climate Change with a Comprehensive US Cap-and-trade System’ (2008) 24(2) Oxford Review of Economic Policy 298, 305.

61 广东省人民政府 [People’s Government of Guangdong Province], above n 41.

62 Ibid.

63 Tuerk et al, above n 3, 15 .

64 广东省人民政府 [People’s Government of Guangdong Province], above n 41. 
determinants of policy cost and its climate benefits. ${ }^{65}$ As the climate issue is a long-term problem, there is significant flexibility to decide when to actually carry out measures to achieve emissions reductions. ${ }^{66}$ Phased-in targets, including short-term targets, medium-term targets and long-term targets, are introduced into the policies to deal with this 'when flexibility'. ${ }^{67}$ Given that the pilot period in most pilot regions lasts only two to three years (20132015), medium-term and long-term targets are not taken into account here. Generally speaking, short-term targets with stringent caps may be associated with many costs due to the sacrifice of a continued high economic growth rate. However, these costs can be avoided by setting annual emission targets that gradually increase in stringency. ${ }^{68}$ In addition, gradually phased-in targets provide time to apply advanced technologies in long-term investments. ${ }^{69}$ Therefore, it would be ideal to set gradually phased-in emissions targets in these pilot ETS programs. Based on the local level of economic development, policymakers in each pilot region could set an emissions target with a gradually increasing trajectory of emissions reductions over time. A longterm, gradually phased-in emissions target could be set by local policymakers during the post-2015 period as preparation for a national roll out. In case a national ETS is established afterwards, the NDRC should determine how many emissions allowances they will issue, which defines the system's cap over the entire country. ${ }^{70}$ The NDRC along with the Local Development and Reform Commissions ('LDRCs') should then determine how many emissions allowances should be allocated in each region.

\section{Emissions Allowance Distribution}

Allowances for $\mathrm{CO}_{2}$ emissions distributed to participating enterprises are allocated by the LDRCs based upon the historical emission levels of the particular enterprises and types of industry, and according to the development stage of the reduction scheme. Distribution methods for allowances are

\footnotetext{
${ }^{65}$ Sergey Paltsev et al, 'Assessment of US Cap-and-Trade Proposals' (Working Paper No 13176, National Bureau of Economic Research, June 2007) 3.

${ }^{66}$ Stavins, above n 60, 303.

${ }^{67}$ Ibid.

${ }^{68}$ Ibid.

${ }^{69}$ Adam B Jaffe, Richard G Newell and Robert N Stavins, 'Energy-Efficient Technologies and Climate Change Policies: Issues and Evidence' (John F Kennedy School of Government, Harvard University, Faculty Research Working Papers Series, Climate Issues Brief No 19, Resources for the Future, 1999).

${ }^{70}$ The overall volume of GHGs that can be emitted by sources covered by the ETS is limited by a 'cap' on the number of emissions allowances. Within the cap, enterprises receive or purchase emissions allowances which can be traded as needed. See European Commission, Allowances and Caps (31 October 2013) European Commission Climate Action $<$ http://ec.europa.eu/clima/policies/ets/cap/>.
} 
described in a general manner by local governments in pilot ETS implementation plans, which are different from region to region and are expected to be further detailed by local governments.

\section{$1 \quad$ Beijing}

According to the Beijing Pilot Implementation Plan, initial allowances for $\mathrm{CO}_{2}$ emissions in 2013 were allocated based upon enterprises' historical emissions during 2009-2011 and were allocated to participating enterprises at no cost before December 2012. ${ }^{71}$ The initial allocation for $\mathrm{CO}_{2}$ emissions allowances in 2014 and 2015 will be based upon enterprises' $\mathrm{CO}_{2}$ emissions of the previous year, and these emissions allowances will be distributed before May of every year. ${ }^{72}$ During the Twelfth Five-Year Plan period, in addition to the free emissions allowances, local governments will reserve a small number of allowances that will be allocated through auction. ${ }^{73}$ However, there is no clear definition of how these reserved allowances will be used. Some guess that they are reserved for new entrants. ${ }^{74}$ Furthermore, the cost of carbon reduction, which may differ significantly among different industries, is not mentioned in the allowances allocation in Beijing's Pilot Implementation Plan. It is obvious that industries with higher carbon reduction costs would bear a heavier economic burden than industries with lower carbon reduction costs if allowances are allocated equally. This would have a negative impact on industries with higher carbon reduction costs; in particular it would weaken their competitiveness. Therefore, the cost of carbon reduction in each industry should be taken into account when allowances are distributed. For example, the EU ETS provides that industries with higher carbon reduction costs tend to receive more allowances, whereas fewer allowances are allocated to industries with lower carbon reduction costs. This rule could be introduced into China's pilot emissions trading programs. With such a rule, the most burdened industries are compensated, which contributes to the establishment of consensus on an ETS.

\section{Shanghai}

The initial allocation of $\mathrm{CO}_{2}$ emissions allowances is based on pilot enterprises' historical $\mathrm{CO}_{2}$ emissions during 2009-2011, and each year's $\mathrm{CO}_{2}$ emissions allowances during 2013-2015 are allocated in one shot upon a specific industry's allowances allocation approach. ${ }^{75}$ A sectoral baseline

\footnotetext{
71 李梅影 [Li Meiying], above n 48.

${ }^{72}$ Ibid.

${ }^{73}$ Ibid.

${ }^{74}$ Tuerk et al, above n 3, 16.

75 上海市人民政府 [Shanghai Municipal People’s Government], above n 41.
} 
method may be adopted for allowance distribution in some sectors if it would be feasible, ${ }^{76}$ although there is no definition of the so-called sectoral baseline method. During the pilot period, initial allowances of $\mathrm{CO}_{2}$ emissions are freely allocated, while auctions may be implemented progressively. ${ }^{77}$ However, no explicit definition of the timetable for implementing auctions has been given so far for Shanghai.

\section{Guangdong}

As in Shanghai's pilot ETS implementation plan, the initial distribution of $\mathrm{CO}_{2}$ emissions allowances in Guangdong is based on pilot enterprises' historical $\mathrm{CO}_{2}$ emissions during 2010-2012, and each year's $\mathrm{CO}_{2}$ emissions allowances during 2013-2015 are allocated by the LDRC in one shot depending upon the types of industry. ${ }^{78}$ Unlike the Beijing and Shanghai plans, Guangdong's pilot ETS implementation plan indicates explicitly that a user pays system will be adopted in allowance allocation - that is, with free allocation as the main distribution method and auctions as complementary during the initial stage. ${ }^{79}$ The LDRC will estimate $\mathrm{CO}_{2}$ emissions for investment projects of new fixed assets with an annual total energy consumption above 10000 tons of standard coal. ${ }^{80}$ Based on the estimates of these projects and the provincial annual total emissions target, allowances will be totally or partially allocated at no cost. ${ }^{81}$ However, no clear definition of the number of allowances reserved for new entrants is given in this implementation plan.

The allowance allocation method in Guangdong's pilot ETS implementation plan is more or less the same as the EU ETS. During the first period of the EU ETS (2005-2007), allowances were distributed to entities at almost no cost. The number of grandfathered allowances freely allocated to each plant in the Member State was determined by each member state's own National Allocation Plan ('NAP') according to its national criteria. ${ }^{82}$ The NAPs of Member States, however, did not reflect the demand of the carbon market correctly. Even though the European Commission had substantially revised 15 NAPs by reducing the overall cap by 4.6 per cent, allocated allowances surpassed verified emissions every year during this period, which led to a

\footnotetext{
${ }^{76}$ Ibid.

${ }^{77}$ Ibid.

78 广东省人民政府 [People’s Government of Guangdong Province], above n 41.

${ }^{79}$ Ibid.

${ }^{80}$ Ibid.

${ }^{81}$ Ibid.

${ }^{82}$ Frank Venmans, 'A Literature-Based Multi-Criteria Evaluation of the EU ETS' (2012) 16 Renewable and Sustainable Energy Reviews 5493, 5494.
} 
drastic drop in price in April 2006, from €29.20/t $\mathrm{CO}_{2}$ on Monday, 24 April to a closing spot price of $€ 13.35 / \mathrm{t} \mathrm{CO}_{2}$ at the end of that week. ${ }^{83}$ In contrast to the freely allocated grandfathered allowances, less than five per cent of the allocations per member state were allowed to be auctioned during this period. ${ }^{84}$ Compared to the first period, the share of auctions increased up to 10 per cent of the allocations per member state during the second period of the EU ETS (2008-2012) ${ }^{85}$ The ratio of auctions will further increase during the third trading period of the EU ETS (2013-2020). Over 40 per cent of the allowances are expected to be auctioned from the beginning of the third phase, with a gradual increase of auctioning to 100 per cent in $2027 .^{86}$

It can be seen that the allowances were distributed in a more generous manner (through free allocation) during the early years of the EU ETS, with the distribution gradually becoming more rigorous (through, for example, auctioning) over time. Auctioning is the most transparent allocation method, allowing market participants to obtain the allowances at market price. ${ }^{87}$ Moreover, given that auctioning generates government revenue that can be put towards innumerable uses, it is recognised that auctioning has the potential to reduce a climate policy's economy-wide costs. An oft-cited example of this is that government revenues raised by selling emissions allowances (auction revenue) may sufficiently offset the need to raise revenue through distortionary taxes on desirable assets such as capital (corporate income, dividends or capital gains) and labour (earned income). ${ }^{88}$ A GHG ETS would yield not only an environmental dividend but also an economic

\footnotetext{
${ }^{83}$ Ibid.

${ }^{84}$ The European Parliament and the Council of the European Union, above n 49, L 275/36, Art 10. However, only Hungary, Ireland and Lithuania actually held auctions. See Venmans, above $n$ 82, 5494-5.

${ }^{85}$ Joachim Schleich, Karoline Rogge and Regina Betz, 'Incentives for energy efficiency in the EU Emissions Trading Scheme' (2009) 2(1) Energy Efficiency 37, 37-67.

${ }^{86}$ European Commission, Auctioning (18 November 2013) European Commission Climate Action <http://ec.europa.eu/clima/policies/ets/cap/auctioning/index_en.htm>. However, the aviation sector will continue to receive freely allocated allowances at 85 per cent. See the European Parliament and the Council of the European Union, 'Directive 2009/29/EC of the European Parliament and of the Council of 23 April 2009: amending Directive 2003/87/EC so as to improve and extend the greenhouse gas emission allowance trading scheme of the Community' (23 April 2009) Official Journal of the European Union L 140/63, L 140/63-87 $<$ http://eur-lex.europa.eu/LexUriServ/LexUriServ.do?uri=OJ:L:2009:140:0063:0087:en: PDF>.

${ }^{87}$ European Commission, above $n 86$.

${ }^{88}$ Anne E Smith, Martin T Ross and W David Montgomery, 'Implications of Trading Implementation Design for Equity-Efficiency Trade-Offs in Carbon Permit Allocations' (Working Paper, Charles River Associates, 2002) 3.
} 
one, a phenomenon referred to as the 'double dividend'. ${ }^{89}$ Bovenberg and Goulder's studies show that 'recycling' auction revenue through reducing personal income tax rates could offset 40 to 50 per cent of the economy-wide social costs that a cap would impose if allowances were freely allocated. ${ }^{90}$ However, it is not appropriate to auction all the allowances during the early stage. Although free allocation of allowances would reduce the potential efficiency improvements from revenue-recycling, which could be realised by auctioning, it could affect the distribution of a climate policy's economic impacts by redistributing a cap's economic burden. Allocating more free allowances to the most affected and burdened entities (for example, industries with higher carbon reduction costs) is an example of this. However, given that freely allocating all allowances in perpetuity to affected entities would significantly overcompensate them for their financial losses in aggregate, ${ }^{91}$ the share of allowances that are freely allocated should diminish over time until there is no free distribution into the program. Therefore, it is reasonable and feasible to distribute the allowances freely at the initial stage of the program, moving steadily to 100 per cent distribution through auction over time.

\section{E 'Cost-Containment’ Mechanisms}

Allowance banking and borrowing are often used as 'cost-containment' mechanisms to reduce the undesirable consequences of cost uncertainty. ${ }^{92}$ Generally speaking, borrowing ${ }^{93}$ is prohibited during the pilot period in these

\footnotetext{
${ }^{89}$ The concept of the 'double dividend' is related to environmental taxes (eg, the carbon tax). Given that auction revenues from the ETS function similarly to revenues from environmental taxes, the double dividend exists in both systems. For more discussion about the double dividend, see Lawrence H Goulder, 'Environmental Taxation and the "Double Dividend”: A Reader's Guide' (1995) 2(2) International Tax Policy Forum 157, 157-83; Don Fullerton and Gilbert E Metcalf, 'Environmental Taxes and the Double-Dividend Hypothesis: Did You Really Expect Something for Nothing?’ (1998) 73(1) Chicago-Kent Law Review 221, 221-56.

${ }^{90}$ A Lans Bovenberg and Lawrence H Goulder, 'Confronting Industry-Distributional Concerns in US Climate-Change Policy' (Discussion Paper No 6, Institute on the Economics on the Environment and Sustainability, 2003).

${ }^{91}$ Lawrence $\mathrm{H}$ Goulder, 'Confronting the Adverse Industry Impacts of $\mathrm{CO}_{2}$ Abatement Policies: What Does it Cost?' in Michael A Toman (ed), Climate Change Economics and Policy: An RFF Anthology (Resources for the Future, 2001) 125, 125-33; Smith et al, above n 88, 4; Bovenberg and Goulder, above n 90.

${ }^{92}$ Allowance banking and borrowing under an ETS provide participating enterprises with the flexibility to shift their emission reductions obligations across periods when confronting unexpected and temporarily high or low costs.

${ }^{93}$ The borrowing of allowances allows participating enterprises to under-comply with their emission reductions obligations and use (borrow) allowances that will be issued in future years by shifting the deficit forward to the obligations in subsequent periods. See Robert $\mathrm{N}$ Stavins, 'Experience with Market-Based Environmental Policy Instruments' in Karl-Göran
} 
pilot regions, given that the pilot period is relatively short and there are too many uncertainties for the post-2015 nationwide ETS, which is expected to be linked with regional ETSs. However, banking ${ }^{94}$ is allowed under specific conditions within the pilot phase.

According to Beijing's Pilot Implementation Plan, banking of allowances is allowed but no allowances are valid after $2015 .^{95}$ The purpose of this rule is to boost the liquidity of allowances, given that allowances allocated to participating enterprises may not be appropriate during the initial stage and the long-term possession of these allowances may have side effects on the future carbon market. However, this rule will discourage participating enterprises from creating tradable allowances through low-carbon and energysaving technologies, since these allowances will become invalid in the post2015 period. Therefore, further studies on the definition of allowance banking and the period during which it will be available are necessary in the near future.

There is only one general regulation controlling allowances banking and borrowing in Shanghai's pilot ETS implementation plan, allowing banking to go beyond the end of the year. ${ }^{96}$ However, details of the use of allowances after 2015 are not given in this pilot ETS implementation plan, causing uncertainties for the post-2015 carbon market.

As with Beijing and Shanghai, no allowances are valid after 2015 in Guangdong's pilot ETS program, even though banking is allowed within the pilot period. ${ }^{97}$ Further precise details on the definition and use of post-2015 banking are expected to be given by LDRC.

Regulations that have been made concerning banking of allowances in China are similar to those applying during the first period of the EU ETS (20052007). To deal with the price crash caused by over-allocated allowances during the first period of the EU ETS, banking of the allowances within the first period was allowed, but not during the time between the first period and

Mäler and Jeffery R Vincent (eds), Handbook of Environmental Economics, Volume 1: Environmental Degradation and Institutional Responses (Elsevier Science and Technology, May 2003) 355-435.

94 The banking of allowances allows participating enterprises to undertake extra emission reductions (over-comply) earlier and save (bank) unused allowances for use in future years. See Stavins, ibid.

95 李梅影 [Li Meiying], above n 48.

96 上海市人民政府 [Shanghai Municipal People’s Government], above n 41.

97 广东省人民政府 [People’s Government of Guangdong Province], above n 41. 
the second period. ${ }^{98}$ Consequently, the carbon price plunged to its lowest level at the end of the first period, ending at $€ 0.08 / \mathrm{t} \mathrm{CO}_{2}$ by the end of 2007. The lesson of Europe should be learned by China's pilot ETS programs. Should a post-2015 national ETS be established in China, banking of allowances should be permitted between the pilot ETS programs ceasing and the national ETS coming into force.

\section{F Monitoring, Reporting, Verification}

Monitoring systems which enable the credible measurement, reporting and verification of carbon emissions trading activities are critical for the successful implementation of an ETS. ${ }^{99}$ According to the Chinese regions' pilot ETS implementation plans, MRV works in all three pilot regions are conducted by designated third parties assigned by local governments. It is obvious that local enterprises will usually be preferred as MRVs by local governments, since they are more familiar with the local enterprises participating in these pilot ETS programs. Strictly speaking, these local enterprises preferred by local governments are not third parties - that is, parties at arm's length from government - but more like government appointees. This could have repercussions for the efficacy of MRV works. Moreover, there could also be problems when pilot ETS programs are transformed into a national ETS where there is no 'local' preference. Therefore, an independent third party without any local government preference should be responsible for MRV works. For example, a group of independent third party auditors could be designated by the NDRC and then be sent to local regions to undertake MRV works separately.

The reporting system is established in Beijing's Pilot Implementation Plan, indicating that all mandatory participating enterprises are required to report their energy consumption and emission factors data and submit their verified annual $\mathrm{CO}_{2}$ emissions to LDRC by March of the following year, which will serve as the basis for the new allocation of allowances that will be issued in May of the following year. ${ }^{100}$ The Beijing municipal government is also considering establishing administrative measures on carbon emissions trading in Beijing to define the rights and obligations of the third-party verifier before

\footnotetext{
${ }^{98}$ Venmans, above n 82, 5494.

${ }^{99}$ UN-REDD Programme, Measurement Reporting and Verification (26 October 2013) <http://www.unredd.org/UNREDDProgramme/InternationalSupport/MeasurementReportinga ndVerification/ tabid/1050/language/en-US/Default.aspx>.

100 Tuerk et al, above n 3, 16 .
} 
the Carbon Emissions Trading Market Regulation in Beijing is released by 2015. ${ }^{101}$

The establishment of MRV is explicitly put forward in Shanghai's pilot ETS implementation plan in a general manner, without any concrete provisions. According to this implementation plan, both pilot enterprises and reporting enterprises are required to report their $\mathrm{CO}_{2}$ emissions of last year within the stipulated time; these reports will be verified by a third-party verifier. ${ }^{102}$

Compared to MRV in Beijing and Shanghai, MRV in Guangdong is more precisely regulated in its pilot ETS implementation plan, requiring both emissions-control enterprises and industrial sector enterprises with annual $\mathrm{CO}_{2}$ emissions during 2011-2014 above 10000 tons (or with annual total energy consumption above 5000 tons of standard coal) to report their $\mathrm{CO}_{2}$ emissions. ${ }^{103}$ Key enterprises from the transport and building sectors will be required to conduct reporting activities as well as research. ${ }^{104}$ In a bid to establish the verification system for $\mathrm{CO}_{2}$ emissions of emissions-control enterprises, third-party verifiers with relevant qualifications are trained and authorised by local government to verify the information of $\mathrm{CO}_{2}$ emissions reported by emissions-control enterprises. ${ }^{105}$ As a convenience for participating enterprises and third-party verifiers, a relevant Electronic Information System is expected to be instituted to establish MRV in Guangdong. ${ }^{106}$

Compared to the general and rough regulations in relation to MRV in these pilot Chinese ETS implementation plans, MRV provisions in the EU ETS are more detailed and explicit. The annual MRV procedure and processes connected to the procedure are referred to as the 'compliance cycle' of the EU ETS. ${ }^{107}$ In accordance with the EU ETS Directive, the European Commission has adopted guidelines for the monitoring and reporting of GHG emissions. ${ }^{108}$ During the third period of the EU ETS (2013-2020), the EU ETS MRV is required to comply with two new EC regulations - one pertaining to monitoring and reporting and the other specific to verification and

\footnotetext{
101 李梅影 [Li Meiying], above n 48.

102 上海市人民政府 [Shanghai Municipal People’s Government], above n 41.

103 广东省人民政府 [People’s Government of Guangdong Province], above n 41.

${ }^{104}$ Ibid.

${ }^{105}$ Ibid.

${ }^{106}$ Ibid.

${ }^{107}$ European Commission, Monitoring, Reporting and Verification of EU ETS Emissions (31 October 2013) European Commission Climate Action <http://ec.europa.eu/clima/ policies/ets/monitoring/>. ${ }^{108}$ Ibid.
} 
accreditation. ${ }^{109}$ In order to encourage more harmonised and cost-effective application of the regulations in all Member States, the electronic templates for monitoring plans have been published by the EC. ${ }^{110}$ These measures, which could be introduced to China's ETS, have improved the administrative efficiency and harmony of MRV. If China takes advantage of the experience from the EU ETS MRV, the monitoring and reporting of GHG emissions in China would be more robust, transparent, consistent and accurate, which is essential for the effective operation of the ETS.

\section{G Trading Platform}

Carbon emissions trading activities are conducted through trading platforms, which are clearly designated by local governments. For example, the trading platform in Shanghai is the Shanghai Environment and Energy Exchange (SEEX), ${ }^{111}$ while Guangdong's trading platform is the Guangzhou Carbon Emission Rights Exchange. ${ }^{112}$ The trading platform in Beijing will be set up in the Administrative Measures on Carbon Emissions Trading in Beijing. ${ }^{113}$ Only Guangdong clearly elaborates its intention to explore inter-provincial carbon emissions trading mechanisms, which will link up Guangdong's ETS with ETSs in other provinces, although no further data are given in its pilot ETS implementation plan. With regard to inter-provincial carbon emissions trading, China could also benefit from the EU ETS's successful experience with interstate carbon emissions trading.

\section{H Issues concerning Competitiveness and Carbon Leakage}

Competitiveness and carbon leakage are two major issues to be addressed when discussing a cap-and-trade system or ETS. Given that these factors may have negative impacts on the economy and environment, policymakers usually pay more attention to them when designing and implementing ETSs. However, no specific and explicit guidance with regard to these issues is given in the pilot ETS implementation plans of the Chinese regions. This is not because they are ignored by policymakers, but because these issues are unlikely to emerge during the pilot phase. For one thing, both local governments and participating enterprises believe that first movers should

\footnotetext{
109 Ibid.

${ }^{110}$ Ibid.

111 上海市人民政府 [Shanghai Municipal People’s Government], above n 41.

112 广东省人民政府 [People’s Government of Guangdong Province], above n 41.

113 李梅影 [Li Meiying], above n 48.
} 
have first-mover advantages in the development of a low-carbon economy once a nationwide ETS is implemented. These future advantages will stimulate their enthusiasm to conduct pilot ETSs actively. Enterprises which are not concerned about effects on their competitiveness will tend to be positive and optimistic.

On another issue, some sources have indicated that the NDRC has signalled that a nationwide ETS will be implemented by the Chinese government during the Thirteenth Five-Year Plan period (2016-2020). ${ }^{114}$ Pilot regions' governments as well as participating enterprises all accept this assumption which, if it is correct, would tend to minimise negative effects on interprovincial competitiveness, and possible carbon leakage, given that no enterprises can avoid the ETS after 2015. ${ }^{115}$ Given the great uncertainties concerning carbon markets at home and abroad, and the on-going downturn in the EU's carbon market, whether China will establish its nationwide ETS in the near future cannot be predicted. In this climate of uncertainty, countermeasures and solutions responding to these issues are expected to be further studied and put forward by Chinese policymakers.

Theoretically, there are three channels through which carbon leakage is affected by unilateral carbon pricing: (1) the energy price channel or fossil fuel channel; (2) the trade leakage channel or competitiveness leakage channel; and (3) the technology and policy spill-over channel. ${ }^{116}$ The first channel is closely linked with energy markets and macroeconomic effects. It is assumed that a price-induced reduction in fossil fuel demand caused by ambitious environmental policies (such as the ETS) inside a large region (such as the EU) would reduce world prices for oil, gas and coal, which would lead to higher demand and consumption in the parts of the world without such environmental policies and, therefore, increase carbon emissions outside of this region. ${ }^{117}$ The second channel is referred to as the trade leakage channel (or the competitiveness leakage channel), ${ }^{118}$ since the impacts of carbon pricing on firms' production costs are closely connected with the

\footnotetext{
${ }^{114}$ Carbon Market Watch, 'China’s Pilot Emissions Trading Systems’ (2013) 3 Carbon Market Watch Newsletter 11, 12 <http://carbonmarketwatch.org/wp-content/uploads/2013/05/CMW_ Newsletter_2013-05_web.pdf >; IETA, above n 11, 3.

115 Tuerk et al, above n 3, 17.

${ }^{116}$ Dröge et al, above n 30, 16.

${ }^{117}$ Dröge et al, above n 30, 18.

${ }^{118}$ Venmans, above n 82, 5498. Some scholars consider this leakage route as a 'competitiveness leakage channel'. See Julia Reinaud, 'Issues behind Competitiveness and Carbon Leakage: Focus on Heavy Industry' (IEA Information paper, October 2008) 4; Damien Demailly and Philippe Quirion, 'Changing the Allocation Rules in the EU ETS: Impact on Competitiveness and Economic Efficiency' (Climate Change Modelling and Policy Working Papers, Fondazione Eni Enrico Mattei, October 2008) 16.
} 
competitiveness of energy-intensive and trade-exposed ETS industries. With emissions restrictions from the ETS, energy-intensive and trade-exposed ETS industries may lose competitiveness. As a result, they would be expected to change their operation and investment decisions (for example, increase emission-intensive production outside the ETS), which would generate carbon leakages outside the ETS regions. The third channel is referred to as the technology and policy spill-over channel ${ }^{119}$ based on the Porter Hypothesis. ${ }^{120}$ It is assumed that stringent climate policy can induce the development of lowcarbon technologies that make production processes and products more efficient, raising the competitiveness of companies operating in international markets. ${ }^{121}$ With the diffusion and proliferation of low-carbon technologies around the world, carbon-intensity of production in non-ETS regions would be lowered and foreign emissions could be reduced accordingly. In addition to technology spill-overs, the ETS as a role model of climate policy will be diffused outside as well and, therefore, mitigate more emissions outside the ETS region. As opposed to the first two channels, which would cause carbon leakage, the technology and policy spill-over channel could decrease emissions outside the ETS region and offset carbon leakage, decreasing global net emissions to some extent. Therefore, technology and policy spill-over would be an appropriate method to address the issue of carbon leakage.

From the perspective of practice, the experience of carbon leakage in the EU ETS could inform China's ETS programs. Although recent ex ante model estimates of carbon leakage and competitiveness loss vary considerably, ${ }^{122}$ most ex post studies of the EU ETS indicate that an ETS does not significantly influence competitiveness and the EU ETS has not, so far, triggered observable carbon leakage outside the EU. ${ }^{123}$ In general, carbon leakage did

\footnotetext{
${ }^{119}$ Some scholars consider technology spill-overs as a form of carbon leakage. See Arttu Makipaa et al, 'Competitive Distortions and Leakage in a World of Different Carbon Prices: Trade, Competitiveness and Employment Challenges when Meeting the Post-2012 Climate Commitments in the European Union' (Climate Strategies Report, 2008); Lena Neij and Kerstin Astrand, 'Outcome Indicators for the Evaluation of Energy Policy Instruments and Technical Change' (2006) 34(17) Energy Policy 2662, 2662-76; Terry Barker et al, 'Carbon Leakage from Unilateral Environmental Tax Reforms in Europe, 1995-2005’ (2007) 35(12) Energy Policy 6281, 6281-92; Michael E Porter and Forest L Reinhardt, 'Grist: A Strategic Approach to Climate’ (2007) 85(10) Harvard Business Review 22, 22-6.

${ }^{120}$ This hypothesis was formulated by the economist Michael Porter in 1995. See Michael E Porter and Claas van der Linde, 'Toward a New Conception of the EnvironmentCompetitiveness Relationship’ (1995) 9(4) Journal of Economic Perspectives 97.

${ }^{121}$ Dröge et al, above n 30, 16.

${ }^{122}$ Different recent ex ante analyses of estimates of carbon leakage and competitiveness loss are summarised by Venmans. See Venmans, above n 82, 5499 Table 2.

${ }^{123}$ For example, Anger and Oberndorfer apply an econometric ex post regression analysis for 419 German ETS firms and find that the allocation factor does not affect revenues or employment. See Niels Anger and Ulrich Oberndorfer, 'Firm Performance and Employment
} 
not occur through the trade channel during the first phase of the EU ETS. This result is not surprising, given that the ETS industries were on average 100 per cent grandfathered in during the first phase of the EU ETS, and the mean profitability of ETS plants was therefore increased. ${ }^{124}$ Meanwhile, overallocation for industrial sectors during the first phase lowered the risk of carbon leakage outside the EU as well. Although over-allocation did not occur during the second phase of the EU ETS, a significant dip in carbon prices caused by the Global Financial Crisis reduced the cost of emissions inside the EU and did not decrease the world energy price as well. Thus, carbon leakage would not be able to occur through either the trade leakage channel or the energy price channel. Moreover, low-carbon technology development induced by the EU ETS also has a long-term positive effect on the competitiveness of ETS industries, providing first-mover advantages for European producers, which can effectively control carbon leakage that occurs through the competitiveness leakage channel. Although carbon leakage was lower than observable during the first and second periods of the EU ETS, continuous monitoring is required given that leakage is difficult to detect over a short time frame. ${ }^{125}$ Considering that free allocation will gradually be displaced in the future by auctioning, and that present anti-leakage measures are costly, ${ }^{126}$ carbon leakage may present new challenges during the third phase of the EU ETS. In response, scholars are proposing a continuous analysis of carbon leakage. For example, Reinaud emphasises that it is important to analyse carbon leakage from the perspectives of the cost pass-through capacity, trade flows and investment decisions, which are three important indicators of carbon leakage. ${ }^{127}$ Given that carbon leakage is affected by carbon pricing through the above-mentioned three channels, it is essential to understand how to prevent and control carbon leakage through the energy price channel and the trade leakage channel, while spreading climate policies and low-carbon technologies across the world to eliminate carbon leakage.

\footnotetext{
in the EU Emissions Trading Scheme: An Empirical Assessment for Germany’ (2008) 36(1) Energy Policy 12, 12-22. Reinaud concludes that the EU ETS has not resulted in a significant carbon emissions increase in the steel, cement and primary aluminium sectors. See Reinaud, above $\mathrm{n} 118$.

${ }^{124}$ Venmans, above n 82, 5501.

125 Ibid 5508.

126 Ibid 5501.

${ }^{127}$ The cost pass-through capacity of a sector is its ability to recover the cost of the carbon constraint on product prices, without significantly undermining international competitiveness, ie, without inducing carbon leakage. See Reinaud, above n 118, 5-6.
} 


\section{Pilot ETSs With Official Implementation Plans: TIANJIN, HUBEI AND SHENZHEN}

Following Beijing, Shanghai and Guangdong, Tianjin and Hubei published their pilot ETS implementation plans in February 2013. In June 2013, the NDRC approved the pilot ETS implementation plan in Shenzhen. Following the approval of Shenzhen's implementation plan, China's first carbon trading market was launched in Shenzhen on 18 June 2013.

\section{A Tianjin}

The Implementation Plan for Pilot Carbon Emissions Trading Programs in Tianjin ('Tianjin's Pilot Implementation Plan') was published by Tianjin Municipal People's Government on 5 February 2013. ${ }^{128}$ Before this official implementation plan was issued, a series of policies had been implemented to pave the way for ETS in Tianjin. One of the most important policies is the General Plan for the Development of Emissions Trading Market of Tianjin released by the Tianjin Development and Reform Commission on 18 June 2011, ${ }^{129}$ providing the means of establishing an integrated ETS that includes major pollutants (such as $\mathrm{SO}_{2}$ and $\mathrm{COD}$ ) and $\mathrm{CO}_{2}$. Furthermore, concrete actions were introduced to put $\mathrm{CO}_{2}$ emissions trading on track as well. For example, the Energy Efficiency Trading Implementation Plan for Civil Building in Tianjin was issued on 20 January $2010,{ }^{130}$ becoming the first legal instrument of the ETS in the field of civil building in China.

According to Tianjin's Pilot Implementation Plan, enterprises from the sectors of iron and steel, chemicals, electricity, heating power, petrochemicals, oil

\footnotetext{
128 天津市人民政府办公厅 [General Office of Tianjin Municipal People’s Government], 《天 津市人民政府办公厅关于印发天津市碳排放权交易试点工作实施方案的通知》 [Circular of General Office of Tianjin Municipal People's Government on Printing and Distributing the Implementation Plan for Pilot Carbon Emissions Trading Programs in Tianjin] (5 February 2013) 天津市人民政府 Tianjin Municipal People’s Government <http://www.tj.gov.cn/zwgk/wjgz/szfbgtwj/201303/t20130304_188946.htm>.

129 天津市发展和改革委员会 [Tianjin Development and Reform Commission], 《关于天津 排放权交易市场发展的总体方案》 [General Plan for the Development of Emissions Trading Market of Tianjin] (18 June 2011) 天津市人民政府公报 Tianjinshi Renminzhengfu Gongbao <http://www.tjzb.gov.cn/system/2011/09/26/000258239.shtml>.

130 天津市城乡建设和交通委员会, 天津市发展和改革委员会, 天津市经济和信息化委员会, 天津市环境保护局, 天津市财政局 [Tianjin Construction and Traffic Committee, Tianjin Development and Reform Commission, Tianjin Economic and Information Commission, Tianjin Environmental Protection Bureau and Tianjin Finance Bureau], 《天津市民用建筑能 效交易实施方案》 [Energy Efficiency Trading Implementation Plan for Civil Building in Tianjin] (20 January 2010) 天津市政府信息公开 Tianjin Municipal People’s Government Information Publicity <http://www.tjzfxxgk.gov.cn/tjep/ConInfoParticular.jsp?id=19904>.
} 
and gas exploitation, as well as civil building, with annual $\mathrm{CO}_{2}$ emissions since 2009 higher than 20000 tons, will be included in the initial pilot period. ${ }^{131}$ This market scope will be expanded gradually upon the development of Tianjin's as well as the nationwide carbon markets.

An absolute cap is required to be set during the pilot period, although no quantitative cap is given in this implementation plan. The initial allocation of allowances during 2013-2015 is based on the annual total emissions target and historical emissions of participating enterprises. ${ }^{132}$ Allowances are allocated freely to participating enterprises during the pilot period, while auctioning is being explored for future allocation. ${ }^{133}$

An MRV system has been established to facilitate the pilot ETS program in Tianjin, and MRV works are conducted by designated third parties assigned by the government of Tianjin. ${ }^{134}$ The trading platform is the Tianjin Emission Rights Exchange ('TEREX'), through which carbon emissions trading in Tianjin can be conducted in an open, fair and impartial manner. ${ }^{135}$ First, it helps enterprises to manage their environmental risks and disclose environmental information. Second, in order to ensure fair trading, TEREX provides transparent trading prices to each participant. Finally, the credibility of the environmental trading market is assured through standardised trading procedures.

\section{B Hubei}

The Implementation Plan for Pilot Carbon Emissions Trading Programs in Hubei Province ('Hubei's Pilot Implementation Plan') was released by the government of Hubei Province on 18 February 2013, ${ }^{136}$ dividing this pilot program into four phases. Research work on the pilot ETS as well as the preparatory work were undertaken during Phase I (December 2011-June 2012). Phase II (July 2012-June 2013) was the launching period, and Hubei’s

\footnotetext{
131 天津市人民政府办公厅 [General Office of Tianjin Municipal People’s Government], above $n 128$.

${ }^{132}$ Ibid.

${ }^{133}$ Ibid.

${ }^{134}$ Ibid.

135 Ibid.

136 湖北省人民政府办公厅 [General Office of the Government of Hubei Province]，《省人民 政府办公厅关于印发湖北省碳排放权交易试点工作实施方案的通知》 [Circular of General Office of the Government of Hubei Province on Printing and Distributing the Implementation Plan for Pilot Carbon Emissions Trading Programs in Hubei Province] (18 February 2013) 湖北省环境保护 厅 Hubei Environmental Protection Bureau <http://www.hbepb.gov.cn/zwgk/zcwj/szfwj/201303/t20130304_59436.html>.
} 
Pilot Implementation Plan was accomplished during this period. The pilot ETS program was scheduled to be formally launched in August 2013, bringing in the operation period (Phase III) from August 2013 to June 2015. ${ }^{137}$ During Phase IV (July 2015-December 2015), the pilot program will be assessed and improved to pave the way for a nationwide ETS.

According to this implementation plan, enterprises from key industries with annual total energy consumption during 2010-2011 higher than 60000 tons of standard coal will be included in the mandatory pilot ETS program in Hubei. ${ }^{138}$ In addition to these enterprises, corporations with CCERs, the Carbon Emission Rights Bank in Hubei and other eligible corporations volunteering to participate in carbon emissions trading are encouraged to take part in this pilot ETS program. ${ }^{139}$

At the pilot stage, the trading of Hubei's pilot ETS focuses exclusively on $\mathrm{CO}_{2}$, while other GHGs will be included in this ETS gradually with the development of the pilot program. ${ }^{140}$ Tradable allowances in this pilot ETS consist of freely allocated carbon emissions allowances and CCERs (including forest carbon sinks) generated in Hubei province. ${ }^{141}$ As in Shanghai, auctions of allowances may later be implemented progressively upon the performance of the pilot program, although no explicit timing is given in this implementation plan. ${ }^{142}$ As far as CCERs are concerned, a maximum level is set by the implementation plan, although the precise ratio is not given in this implementation plan. ${ }^{143}$ Generally, the price of allowances is influenced by the carbon market. However, in order to prevent abnormal volatility in the carbon market during the initial period of the pilot program, administrative means are adopted to adjust the carbon market when necessary. ${ }^{144}$

\footnotetext{
${ }^{137}$ This pilot ETS program had not occurred by November 2013, although the local government said that the program would be launched within the year 2013. See 《湖北碳交易年内开闸 153 家企业纳入试点》 [Hubei Will Launch Carbon Trading Within this Year, Intending to Include 153 Enterprises in the Pilot Program] (18 November 2013) <http://finance.chinanews. com/ny/2013/11-18/5515659.shtml>.

138 湖北省人民政府办公厅 [General Office of the Government of Hubei Province], above n 136.

${ }^{139}$ Ibid.

${ }^{140}$ Ibid.

${ }^{141}$ Ibid.

142 Ibid.

${ }^{143}$ Ibid.

${ }^{144}$ Ibid.
} 
Designated third parties are assigned by local government to conduct MRV. In fact, Hubei has a great deal of experience with MRV, a fact which could effectively support the pilot ETS program there. For example, in Wuhan, the capital city of Hubei province, the Guidelines for GHG MRV were published by a carbon emissions trading association on 23 September 2011, and constituted the first local standard for MRV. ${ }^{145}$ Owing to these Guidelines, 20000 tons of GHG were successfully purchased by two export-oriented manufacturing enterprises in Wuhan in September 2011, this purchase becoming the first carbon neutral trade in central China. ${ }^{146}$ The Hubei Emission Rights Exchange Centre will be established to provide a trading platform for both voluntary and pilot emissions trading programs in Hubei province. $^{147}$

\section{Shenzhen}

Unlike Beijing, Shanghai, Tianjin and Chongqing, which are 'municipality cities', Shenzhen is a 'local city', which is part of Guangdong province. It is necessary to clarify the relationship among municipalities, local cities and provinces selected to conduct pilot ETSs. From the political perspective, municipalities, including Beijing, Shanghai, Tianjin and Chongqing, have administrative powers equal to those of the provinces in China. In practice, leaders from municipalities have a greater chance of being promoted to a higher administrative level of the central government than leaders from provinces. Local cities, such as Shenzhen, belong to provinces and have less administrative power than municipalities and provinces, which also have rural administrative areas. ${ }^{148}$ Therefore, China consists of a pyramidal hierarchy of national administrative regions, with municipalities at the top and local cities at the bottom. Power differences among these regions may affect the efficacy of implementation of these pilot ETS programs. However, as opposed to normal local cities, Shenzhen is one of the Special Economic Zones ('SEZs') in mainland China. As selected cities located in mainland China, SEZs have more free market-oriented economic policies and flexible governmental

\footnotetext{
145 翟凌云 [Qu Lingyun], 《武汉率先探索碳排放交易近四年》[Wuhan Has Been Taking the Lead in Exploring Carbon Emissions Trading for 4 Years], 长江日报 Changjiang News (online), 15 January 2012 <http://cjmp.cnhan.com/cjrb/page/1/2012-01-15/5/66941326567 299307.pdf $>5$.

146 Ibid.

147 湖北省人民政府办公厅 [General Office of the Government of Hubei Province], above n 136.

${ }^{148}$ Tuerk et al, above n 3, 14 .
} 
measures than the rest of mainland China. ${ }^{149}$ Considering the specific economic and social status of Shenzhen, it has been selected and separated from Guangdong province to conduct its own pilot ETS program, which could differ from that of Guangdong province.

On 19 September 2012, the Shenzhen local government held a press conference to release information about the progress of preparatory work on its pilot ETS program and to introduce extraordinary measures concerning the pilot program. ${ }^{150}$ The details of the pilot ETS design were that around 800 enterprises from 26 sectors with annual $\mathrm{CO}_{2}$ emissions above 20000 tons were planned to be included in the mandatory pilot ETS program; these enterprises accounted for 54 per cent of total $\mathrm{CO}_{2}$ emissions of Shenzhen in $2010 .{ }^{151}$ Unlike other pilot regions, Shenzhen has no large emitters (such as iron and steel as well as cement industries); therefore more enterprises are included in the pilot ETS so as to ensure that more than half of the total $\mathrm{CO}_{2}$ emissions are included in this pilot program. The Shenzhen local government has completed the allowances allocation plan - the core task in the establishment of a carbon market - indicating that most allowances will be allocated freely during the initial period, with progressive auctioning until 100 per cent of the allowances have been auctioned. ${ }^{152}$ As in Beijing, Shanghai and Guangdong, designated third parties are assigned to conduct MRV works, ensuring the reliability, credibility and quality of the verification. ${ }^{153}$ The trading platform in Shenzhen is the SEEX, the capital of which has been increased from 15 million RMB to 300 million RMB, making it the emission rights exchange with the largest registered capital in China. ${ }^{154}$

In June 2013, the Implementation Plan for Pilot Carbon Emissions Trading Programs in Shenzhen ('Shenzhen's Pilot Implementation Plan') was approved by the NDRC. On 18 June 2013, Shenzhen launched its pilot carbon trading scheme, becoming the first city formally to launch the pilot carbon

\footnotetext{
${ }^{149}$ For more information about the SEZs in China, see Special Economic Zone (SEZ) (24 November 2013) Encyclopaedia Britannica <http://www.britannica.com/EBchecked/topic/ 558530/special-economic-zone-SEZ>.

${ }^{150}$ Details of the press conference are available at $<$ http://www.sz.gov.cn/cn/xxgk/xwfyr/wqhg/ 20120919/>.

151 深圳市人民政府 [Shenzhen Municipal Government]，《深圳市碳排放权交易试点工作新 闻发布会》 [Press Conference of the Work on Pilot Carbon Emissions Trading in Shenzhen] (19 September 2012) 深圳政府在线 Shenzhen China <http://www.sz.gov.cn/cn/xxgk/ xwfyr/wqhg/20120919/>.

${ }^{152}$ Ibid.

${ }^{153}$ Ibid.

${ }^{154}$ Ibid.
} 
emissions trading program in China. ${ }^{155}$ According to Shenzhen's Pilot Implementation Plan, 635 industrial enterprises across the most energyintensive sectors are included in its pilot ETS, accounting for 40 per cent of the city's total GHG emissions. ${ }^{156}$ The 635 industrial enterprises will be issued 100 million emissions allowances over the next three years (20132015), with 33.2 million allowances issued this year. ${ }^{157}$ On the first day of trading at the SEEX, an aggregate of 21112 tons of emissions allowances were traded among participating industries in the spot market, with the price ranging from CN¥28 to CN¥30 (equivalent to US\$4.6 to US\$4.9) per ton. ${ }^{158}$ The initially low price of emissions allowances reached an all-time peak of CN¥130.9 (US\$21) on 17 October 2013, surpassing the California Carbon Allowance (CCA) price which closed at about US\$12 on the same day. ${ }^{159}$ The price of allowances has been continuously increasing since early October, with an 86 per cent increase from CN¥70.6 (US\$11.5) on 8 October 2013 to CN¥130.9 (US\$21) on 17 October 2013 (Figure 2). ${ }^{160}$

Given that China's pilot emissions trading programs are broadly designed upon the EU ETS, it is to be feared that a similar drawback of over-allocation of emissions allowances and the resulting collapse in carbon price will be encountered by China as well. However, the trading scenario up till now has not confirmed previous apprehensions. Although the carbon price keeps on increasing, the trading volume at the SEEX remains within a narrow range, with daily average trades of 211 tons in October 2013. ${ }^{161}$ The relatively low trading volume arises from the uncertainty of the ETS in China. First, it is still uncertain which carbon pricing regime the Chinese government will adopt in the future. Therefore, it is difficult for investors to make a decision among various alternatives (such as a carbon tax). Moreover, there is still no clear

155 《深圳今日正式运行 我国碳排放权交易实质性启动》 [Shenzhen Starts to Run Formally Today, China Begins to Launch Carbon Emissions Trading Substantially] (18 June 2013) $<$ http://news.xinhuanet.com/fortune/2013-06/18/c_124870105.htm>.

156 《深圳碳排放权交易试点运行启动新闻发布稿》 [Press Release of Launching Pilot Carbon Emissions Trading Program in Shenzhen] (June 2013) 深圳排放权交易所 China Emissions Exchange <http://www.cerx.cn/cn/trade_details.aspx?ArticleID=274>.

${ }^{157}$ Climate Connect, Over 20,000 Tons of Emission Permits Traded on Day 1 of Shenzhen ETS at 28 to 30 RMB (19 June 2013) <http://www.climate-connect.co.uk/Home/?q=Over\%2020\% 2C000\%20tons\%20of\%20emission\%20permits\%20traded\%20on\%20Day\%201\%20of\%20Sh enzhen\%20ETS>.

${ }^{158}$ Ibid.

${ }^{159}$ Climate Connect, Shenzhen Carbon Touch a New High of \$21, Surpasses California Carbon (18 October 2013) <http://www.climate-connect.co.uk/Home/?q=Shenzhen\%20carbon\%20 touch\%20a\%20new\%20high\%20of\%20\%2421\%2C\%20surpasses\%20California\%20carbon>. ${ }^{160}$ Ibid.

${ }^{161}$ Ibid. 
guideline on how the CCERs will be included in the ETS, making the carbon price more uncertain.

Price of Carbon Permits at Shenzhen Emissions Exchange

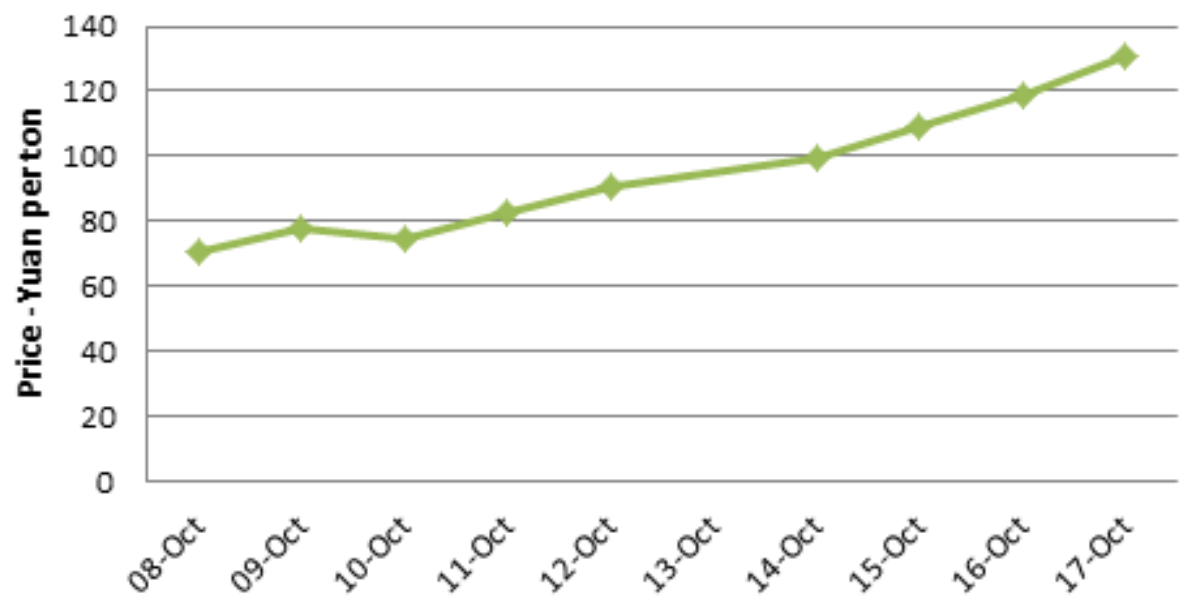

Figure 2: Price of Carbon Emissions Allowances at Shenzhen Emissions Exchange (Source: Climate Connect) ${ }^{162}$

\section{The Pilot ETS Without OfFicial Implementation PLAN: CHONGQING}

At the time of writing, ${ }^{163}$ there is only one pilot region - that is, Chongqing - without an official ETS implementation plan; the local pilot ETS implementation plan has not yet been published. ${ }^{164}$ Chongqing is preparing for the establishment of a pilot ETS, stating that its implementation plan has already been finalised and will be submitted for national approval; it is expected to be published soon. ${ }^{165}$ The chief of the LDRC in Chongqing has disclosed that enterprises included in the pilot ETS in Chongqing will mainly focus on six high energy-consumption industries, including the electrolytic

\footnotetext{
162 Ibid.

163 The data used here are as of 30 September 2013.

${ }^{164}$ Information and data under this heading of the present article have been collected from internet media sources, and may turn out to be different from the final contents of the plan once the local ETS implementation plan is officially published.

165 孟幻 [Meng Huan], 《重庆试点碳排放交易市场纳入森林碳汇交易》 [Pilot ETS in Chongqing Includes the Trade of Forest Carbon Sinks], 中国新闻网 Ecns.cn (online), 26 April $2012<$ http://finance.chinanews.com/ny/2012/04-26/3849689.shtml>.
} 
aluminium, iron alloy, calcium carbide, caustic soda, cement, as well as iron and steel industries. ${ }^{166}$ Furthermore, credits generated from forest carbon sinks will be used in the pilot ETS in Chongqing. Compared with measures taken in the other pilot regions, this is a creative measure. ${ }^{167}$

\section{The Prospects for an ETS in CHINA}

Since the Beijing Municipal Government released its pilot ETS implementation plan in March 2012, the rest of the pilot regions have accomplished their own implementation plans successively, or will finish the implementation plan soon. According to most pilot ETS implementation plans, 2013 is the commencement year of the pilot ETS programs in China, although only Shenzhen has launched its pilot ETS program to date. It is expected that Shanghai, Beijing and Guangdong will launch their pilot ETS programs by the end of 2013. According to the statement of the NDRC, the pilot ETS programs are expected to end in 2015, being replaced by a nationwide ETS during the Thirteenth Five-Year Plan period (2016-2020). ${ }^{168}$

However, it is still not clear whether a nationwide ETS can be successfully established from 2015, or even later, through the bottom-up pilot ETS programs, given that too many uncertainties and difficulties persist. First, pilot ETS programs vary from area to area, ranging from cap setting to allowances allocation. Therefore, cross-regional emission rights exchange will be difficult and complicated to operate. Second, the experience/learning period for the pilot ETSs - 2013 to 2015 - is relatively short, leaving policymakers with too little time to accumulate sufficient information. It is obvious that the current pilot ETS programs at the local level are still immature, and need to be further refined by policymakers. Policymakers who attempt to refine them will be confronted by substantial challenges due to their lack of experience with the more sophisticated requirements of an ETS - in terms of emissions data, administrative capacity and solid regulatory frameworks, which are integral to a robust emissions trading system. ${ }^{169}$ This shortcoming might be overcome through a study of established ETSs, such as those in Europe, the United Kingdom, California and New Zealand, among others; international data on the operation of these systems is available. However, due to national differences, it may not be useful to follow recommendations based on comparative analysis. It will take time to test these recommendations. Third, from an international perspective, the downturn of the EU's carbon market

\footnotetext{
${ }^{166}$ Ibid.

${ }^{167}$ Ibid.

${ }^{168}$ IETA, above $\mathrm{n} 11,3$.

${ }^{169}$ Tuerk et al, above n 3, 18.
} 
serves as a signal to participating enterprises that their mitigation efforts may not bring the expected profits, dampening their enthusiasm for creating emissions allowances. Therefore, industry stakeholders may oppose the implementation of the ETS, which would present more political challenges to enacting such an environmental policy.

Regardless of the abovementioned uncertainties and difficulties, even though a nationwide ETS may eventually be established as expected, there will still be a variety of problems in practice. First of all, it will be necessary to decide whether the nationwide ETS will be a unique trading system or whether it will just include different local ETSs. As discussed above, the liquidity of emissions allowances - that is, the degree to which large transactions of emissions allowances can be carried out in a timely fashion with a minimal impact on the price of allowances - may be restricted due to the different standards and requirements of local ETSs in different regions. Inconsistency in monitoring and verification would also erode the interchangeability of carbon credits from different regions and sectors. Therefore, a trading system with unified standards will be needed to ensure inter-provincial emissions allowances exchange. However, the establishment of unified criteria would present substantial challenges, since there are large differences in economic structures, growth rates, energy consumption and carbon emissions across China's provinces. Further, it is feared that a nationwide ETS with unified standards would worsen China's already substantial regional social and economic disparities.

Secondly, the nature of the nationwide ETS needs to be further clarified before it is established. Policymakers need to determine whether this nationwide ETS is to be voluntary or mandatory like the pilot ETS programs in the seven regions. They also need to identify whether previous pilot regions are to be allowed a transitional period. The articulation point between pilot ETS programs and the nationwide ETS needs to be further explored by the Chinese government in the near future. Moreover, policymakers need to determine whether the emissions cap should be absolute or intensity-based. An absolute emissions cap would make emissions mitigation predictable, but it would conflict with the continued rapid GDP growth in China, since emissions are closely connected with the speed of economic growth. ${ }^{170}$ However, no consensus has been reached on this issue. ${ }^{171}$

\footnotetext{
${ }^{170}$ Marion Davis, Karl Hallding, Guoyi Han and Marie Jürisoo, ‘China’s Carbon Emission Trading: An Experiment to Watch Closely’ (Policy Brief, Stockholm Environment Institute, 2012) 3 .

${ }^{171}$ Davis et al, above $170,4$.
} 
Although the Chinese government has shown its willingness to launch a forthcoming nationwide ETS after 2015, the prospects of the nationwide ETS in China are still not good, given that carbon trading in China is still in its infancy, with much experimentation but few results to date. A variety of issues, such as the system's cap setting, the co-ordination between different pilot programs and the integration of the Chinese carbon market with international trading schemes, among other things, need to be progressively addressed by the Chinese government in the next few years. The success or failure of the experimental pilot ETS programs will, to a large extent, determine the future development of carbon markets in China.

An answer to the question posed at the beginning of this article - which mode of launching a nationwide ETS in China should the Chinese government choose, the revolutionary or the evolutionary? - may now be attempted. The revolutionary mode would establish a nationwide ETS in China in a quick and direct manner; however, this simple and crude way could be expected to sacrifice the individuality of different regions. As discussed above, the pilot ETS implementation plans are not detailed enough, with many regulations needing to be more precisely defined by local governments. For example, instead of just putting forward the objective of auctioning allowances, the government should state the timetable for the auctions more explicitly. Furthermore, experience from past experiments with other kinds of pollution emissions trading (such as $\mathrm{SO}_{2}$ ) and from international ETSs could be applied in China's pilot ETS programs. For example, the detailed and explicit guidelines for the monitoring and reporting of GHG emissions of the EU ETS could inform China's pilot ETS programs. However, a learning-bydoing process is time consuming.

Finally and most importantly, the most fundamental question concerning the launching of an ETS in China is whether this strong market-based instrument can function well in the absence of a mature free-market economy. ${ }^{172}$ In other words, is a free-market economy a prerequisite for the implementation of an ETS? This issue is especially important in China. After more than three decades of market economy-oriented reform, China today is closer than ever to a real market economy. ${ }^{173}$ However, it remains different from a mature free-market economy in that the government still plays an important role in the economy through state-owned enterprises, such as China National Petroleum Corporation and Sinopec, which continue to control the country's economic lifeline. Furthermore, heavy government control and intervention are frequent, and corruption and a culture of distrust in business are widespread. All these factors would have profound implications for the

\footnotetext{
${ }^{172}$ Ibid.

${ }^{173}$ Ibid.
} 
operation of a carbon market, even if the ETS is well designed. Taking these factors into account, it is better to cultivate this embryonic carbon market cautiously rather than exposing it, entirely and directly, to an untested, or insufficiently tested, new environmental policy instrument. In other words, the 'crossing the river by groping for stones' spirit — that is, the mild evolutionary approach — might be more appropriate for the current carbon market in China. The term of the current pilot ETS programs at the local level should be extended step by step before a mandatory nationwide ETS is formally initiated. 